\title{
ANALISIS MODEL MATEMATIKA PROSES PENYEBARAN LIMBAH CAIR PADA AIR TANAH
}

\author{
Oleh: ${ }^{1}$ Arif Fatahillah, ${ }^{2}$ M. Gangga D. F. F. P \\ ${ }_{1,2}$ Program Studi Pendidikan Matematika FKIP Universitas Jember \\ e-mail: arif.fkip@unej.ac.id
}

\begin{abstract}
Abstrak:
Artikel ini bertujuan untuk mengetahui proses penyebaran limbah cair. Computational Fluid Dynamics (CFD) merupakan ilmu sains yang mempelajari tentang aliran fluida yang salah satu diantaranya adalah aliran limbah cair. Data yang digunakan dalam artikel ini adalah data yang telah diperoleh dalam artikel sebelumnya serta beberapa data lainnya dikembangkan dari berbagai literatur, internet, dan sebagainya. Hasil dari penelitian ini pada dasarnya adalah berupa model matematika dari aliran limbah cair pada air tanah dan simulasi dari aliran limbah cair pada air tanah. Model matematika dicari menggunakan metode volume hingga sedangkan untuk simulasi aliran limbah cairnya menggunakan FLUENT, yang mana FLUENT ini merupakan salah satu software dari $C F D$.
\end{abstract}

Kata kunci: Model matematika, Finite Volume Method, Air Tanah, Limbah Cair.

\section{Pendahuluan}

Pencemaran lingkungan saat ini telah menjadi permasalahan yang sangat serius. Hal ini disebabkan oleh meningkatnya populasi manusia, selain itu juga disebabkan oleh perkembangan teknologi industri yang semakin maju. Pencemaran yang terjadi di masyarakat dan alam tidak terbatas wilayah atau tempat dimana pencemaran itu terjadi. Sebagai contoh adalah pencemaran air tanah yang disebabkan oleh limbah cair, hal ini disebabkan limbah tersebut dapat mudah tersebar melalui aliran air tanah.

Air tanah selalu tetap memiliki kemungkinan untuk tercemar oleh polutan. Sumber dan penyebab pencemaran air tanah adalah terkait dengan penggunaan air oleh manusia. Suatu rangkaian perubahan kompleks pada kualitas air tanah yang alami disebabkan oleh berbagai macam aktivitas manusia yang menyangkut sirkulasi perairan.

Untuk membantu menyelesaikan persamaan matematika, maka diperlukan metode yang digunakan untuk menyelesaikan persamaan matematika yang dihasilkan. Adapun metode yang digunakan dalam menyelesaikan persamaan matematika banyak sekali namun untuk kasus ini hanya metode tertentu saja yang dapat digunakan. Metode yang digunakan pada penelitian ini adalah metode volume hingga. Hal ini karena metode volume hingga dapat digunakan pada bentuk benda yang tidak teratur 
sehingga benda menjadi lebih mudah didiskritisasi untuk menentukan nilai-nilai yang akan dicari pada proses diskritisasi. Sehingga dalam menyelesaikan persamaan matematika akan lebih mudah dan bisa menghasilkan solusi yang mendekati nilai sebenarnya.

Hasil dari penelitian ini pada dasarnya adalah berupa model matematika dari aliran limbah cair pada air tanah dan simulasi dari aliran limbah cair pada air tanah. Model matematika dicari menggunakan metode volume hingga sedangkan untuk simulasi aliran limbah cairnya menggunakan FLUENT, yang mana FLUENT ini merupakan salah satu software dari $C F D$.

\section{Metode Penelitian}

Penelitian ini menggunakan teknik dokumentasi dengan mengumpulkan data-data yang diperlukan untuk digunakan. Dalam hal ini mengumpulkan data terkait variabel-variabel yang digunakan dalam analisis sehingga diharapkan bisa mendapatkan hasil yang sesuai dengan keadaan sebenarnya. Pada proses analisis data-data tersebut digunakan dalam proses komputasi menggunakan MATLAB maupun simulasi menggunakan FLUENT.

Peneliti akan memperoleh data yang diinginkan dengan mempelajari buku, jurnal ilmiah serta berbagai data yang diambil dari data-data dari internet. Data yang meliputi massa jenis, tekanan air, konsentrasi limbah dan koefisien difusi akan diperoleh dari data dan catatan pada internet dan buku-buku Groundwater (Air tanah). Berikut hasil dokumentasi masukkan yang digunakan pada penelitian ini:

Tabel 1. Data-data yang Digunakan pada Penelitan

\begin{tabular}{lc}
\multicolumn{1}{c}{ Data yang Digunakan } & Nilai \\
\hline Porositas Efektif $(n)$ & 0,01 \\
\hline Massa Jenis Air $(\rho)$ & $998,2 \mathrm{~kg} / \mathrm{m}^{3}$ \\
\hline Koofisien Difusi $(\mathrm{D})$ & 0,001 \\
\hline Beda tinggi permukaan air $(h)$ & $0,1 \mathrm{~m}$ \\
\hline Jarak antar titik $(l)$ & $20 \mathrm{~m}$ \\
\hline Sumber: Todd, 2005$)$ &
\end{tabular}

Analisis data merupakan bagian akhir dari suatu penelitian. Data yang dikumpulkan selanjutnya diklasifikasikan dan diorganisasikan secara sistematis serta diolah dan dianalisa secara 
3 | al-Khwarizmi, Volume III, Edisi 1, Maret 2015, Hal. 1 - 8.

logis menurut rancangan penelitian yang telah ditetapkan. Analisis data diarahkan untuk memberi argumentasi atau penjelasan mengenai tujuan yang diajukan dalam penelitian, berdasarkan data atau fakta yang diperoleh. Dalam menganalisis juga digunakan analisis efektifitas penggunaan metode dengan menggunakan analisis nilai eror. Dalam analisis tersebut ditetapkan suatu metode dikatan valid jika nilai erornya kurang dari $1 \%$ sehingga nilai tersebut digunakan sebagai acuan untuk menganalisis efektifitas penggunaan metode volume hingga dengan teknik diskritisasi QUICK.

$$
\begin{aligned}
& \phi_{e}(i, j)=-\frac{1}{8} \phi(i-1, j)+\frac{3}{4} \phi(i, j)+\frac{3}{8} \phi(i+1, j) \\
& \phi_{n}(i, j)=-\frac{1}{8} \phi(i, j-1)+\frac{3}{4} \phi(i, j)+\frac{3}{8} \phi(i, j+1) \\
& \phi_{s}(i, j)=-\frac{1}{8} \phi(i, j-2)+\frac{3}{4} \phi(i, j-1)+\frac{3}{8} \phi(i, j) \\
& \phi_{w}(i, j)=-\frac{1}{8} \phi(i-2, j)+\frac{3}{4} \phi(i-1, j)+\frac{3}{8} \phi(i, j)
\end{aligned}
$$

(Fatahillah, 2014)

\section{Hasil dan Pembahasan}

Penelitian ini bertujuan untuk mengetahui penyebaran konsentrasi limbah cair pada air tanah yang didasarkan pada simulasi numerik dan simulasi menggunakan gambar. Dalam analisis digunakan dua persamaan yaitu persamaan momentum dan persamaan kontinuitas massa.

1. Persamaan momentum

$$
\begin{aligned}
& \frac{\partial C_{0}}{\partial t}+\rho v_{x} \frac{\partial C_{w}}{\partial x}-\rho v_{x} \frac{\partial C_{e}}{\partial x}+\rho v_{y} \frac{\partial C_{s}}{\partial y}-\rho v_{y} \frac{\partial C_{n}}{\partial y}=\rho g_{x}+\rho g_{y}-\frac{\partial p}{\partial x}- \\
& \frac{\partial p}{\partial y}+2 \mu \frac{\partial^{2} v_{x}}{\partial x^{2}}+\mu \frac{\partial^{2} v_{x}}{\partial x \partial y}+\mu \frac{\partial^{2} v_{x}}{\partial y^{2}}+2 \mu \frac{\partial^{2} v_{y}}{\partial y^{2}}+\mu \frac{\partial^{2} v_{y}}{\partial x \partial y}+\mu \frac{\partial^{2} v_{y}}{\partial x^{2}}
\end{aligned}
$$

2. Persamaan massa

$$
\frac{\partial C_{0}}{\partial t}+v_{x}\left[\frac{\partial C_{w}}{\partial x}-\frac{\partial C_{e}}{\partial x}\right]+v_{y}\left[\frac{\partial C_{s}}{\partial x}-\frac{\partial C_{n}}{\partial x}\right]=D_{x} \frac{\partial^{2} C}{\partial x^{2}}+D_{y} \frac{\partial^{2} C}{\partial y^{2}}
$$

Dengan menyelesaikan persamaan diferensial untuk setiap persamaan momentum dan persamaan massa. Integrasi dilakukan terhadap $\mathrm{x}, \mathrm{y}$ dan $\mathrm{t}$. 
Analisis Model Matematika ...| 4

Setelah menyelesaikan persamaan integrasi tersebut kemudian akan diperoleh persamaan baru kemudian mensubstitusikan persamaan massa ke persamaan momentum atau sebaliknya. Kemudian persamaan tersebut diselesaikan dengan mengelompokkan berdasarkan arah kecepatan timur, barat, selatan dan utara maka diperoleh persamaan:

$$
\begin{aligned}
& v_{x} \Delta y \Delta t(1-\rho) C_{e}+v_{x} \Delta y \Delta t(\rho-1) C_{w}+ \\
& v_{y} \Delta x \Delta t(1-\rho) C_{n}+v_{y} \Delta x \Delta t(\rho-1) C_{s}= \\
& \rho g \Delta y \Delta t+\rho g \Delta x \Delta t-p \Delta y \Delta t-p \Delta x \Delta t+ \\
& 2 \mu\left(v_{x} \frac{\Delta y \Delta t}{\Delta x}+v_{y} \frac{\Delta x \Delta t}{\Delta y}\right)+\mu\left(v_{x} \Delta t+v_{y} \Delta t\right)+ \\
& \mu\left(v_{x} \frac{\Delta x \Delta t}{\Delta y}+v_{y} \frac{\Delta y \Delta t}{\Delta x}\right)-D_{x} \frac{C \Delta y \Delta t}{\Delta x}-D_{y} \frac{C \Delta x \Delta t}{\Delta y}
\end{aligned}
$$

Kemudian persamaan tersebut diselesaikan dengan metode volume hingga sehingga didapatkan persamaan yang digunakan dalam analisis. Setelah mensubstitusi nilai-nilai kecepatan berarah maka akan didapatkan persamaan:

$$
\begin{aligned}
& \left(-\frac{1}{8 \Delta t}\right) v_{x} \Delta x \Delta y^{2}(\rho-1) C(i-2, j)+\frac{7}{8 \Delta t} v_{x} \Delta x \Delta y^{2}(\rho-1) C(i-1, j)+ \\
& \frac{3}{8 \Delta t} \Delta x \Delta y\left(v_{x} \Delta y+v_{y} \Delta x\right)(1-\rho) C(i, j)+\frac{3}{8 \Delta t} v_{x} \Delta x \Delta y^{2}(1-\rho) C(i+1, j)+ \\
& \left(-\frac{1}{8 \Delta t}\right) v_{y} \Delta x^{2} \Delta y(\rho-1) C(i, j-2)+\frac{7}{8 \Delta t} v_{y} \Delta x^{2} \Delta y(\rho-1) C(i, j-1)+ \\
& \frac{3}{8 \Delta t} v_{y} \Delta x^{2} \Delta y(1-\rho) C(i, j+1)=\frac{\rho y}{\Delta t} \Delta x \Delta y(\Delta y+\Delta x)- \\
& \frac{p}{\Delta t} \Delta x \Delta y(\Delta x+\Delta y)+2 \mu\left(v_{x} \frac{\Delta y^{2}}{\Delta t}+v_{y} \frac{\Delta x^{2}}{\Delta t}\right)+\frac{\mu}{\Delta t} \Delta x \Delta y\left(v_{x}+v_{y}\right)+ \\
& \mu\left(v_{x} \frac{\Delta x^{2}}{\Delta t}+v_{y} \frac{\Delta y^{2}}{\Delta t}\right)-D_{x} \frac{C \Delta y^{2}}{\Delta t}-D_{y} \frac{C \Delta x^{2}}{\Delta t}
\end{aligned}
$$

Persamaan tersebut digunakan dalam analisis numerik menggunakan MATLAB dengan menggunakan nilai-nilai dari variable yang ada berdasarkan data-data yang telah dikumpulkan sebelumnya. Berdasarkan hasil simulasi menggunakan MATLAB didapat hasil simulasi sebagai berikut: 
5 | al-Khwarizmi, Volume III, Edisi 1, Maret 2015, Hal. 1 -8.

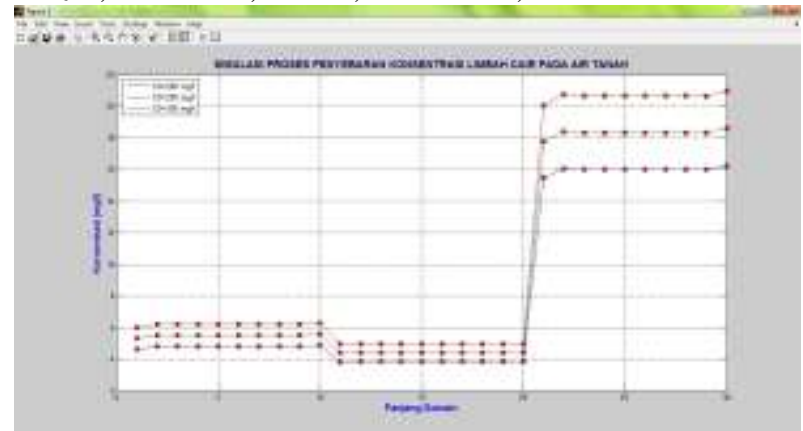

Gambarl. Simulasi dengan Konsentrasi Uji 280mg/l, 290mg/l, \& 300mg/l

Hasil simulasi numerik analisis proses penyebaran limbah cair pada air tanah. Pada grafik Gambar 1. Input yang dimasukkan yaitu diskritisasi sumbu x yaitu 10 sedangkan diskritisasi sumbu y yaitu 3 dengan konsentrasi uji atas sebesar $300 \mathrm{mg} / \mathrm{l}$ dan konsentrasi uji bawah sebesar $280 \mathrm{mg} / \mathrm{l}$ dan waktu selama 1 bulan. Sehingga hasil simulasi penyebaran limbah cair, dapat diketahui pada grafik yang menyimulasikan tiga simulasi konsentrasi penyebaran limbah cair dalam konsentrasi uji $280 \mathrm{mg} / \mathrm{l}, 290 \mathrm{mg} / \mathrm{l}$, dan $300 \mathrm{mg} / \mathrm{l}$. Tampak hasil grafik simulasi dengan konsentrasi uji $280 \mathrm{mg} / \mathrm{l}$ memiliki batas atas konsentrasi limbah yang terbawa oleh air tanah 16,227 $\mathrm{mg} / \mathrm{l}$ dan batas bawahnya sebesar 4,642 mg/l. Sedangkan pada tabel hasil simulasi dengan besar konsentrasi uji 290 mg/l memiliki batas atas konsentrasi limbah yang terbawa oleh air tanah 18,591 $\mathrm{mg} / \mathrm{l}$ dan batas bawahnya sebesar $5,318 \mathrm{mg} / \mathrm{l}$. Pada tabel hasil simulasi dengan konsentrasi uji $300 \mathrm{mg} / \mathrm{l}$, memiliki batas atas konsentrasi limbah yang terbawa oleh air tanah sebesar 20,954 $\mathrm{mg} / \mathrm{l}$ dan batas bawahnya sebesar $5,994 \mathrm{mg} / \mathrm{l}$.

Visualisasi hasil eksekusi program penyebaran limbah cair dengan metode volume hingga dengan konsentrasi uji bawah 280 $\mathrm{mg} / \mathrm{l}$, konsentrasi uji atas $300 \mathrm{mg} / \mathrm{l}$ seperti tersaji pada seperti tersaji pada Gambar 1. Pada titik dengan kelipatan diskritisasi sumbu $\mathrm{x}$, memiliki nilai kecepatan yang tidak jauh berbeda. Kecepatannya akan turun pada panjang domain selanjutnya dan kemudian kembali naik. Hal ini dikarenakan terjadinya pencampuran 2 zat yaitu air tanah dan limbah cair, daerah yang memiliki kecepatan besar ada pada daerah yang berdampingan dengan inlet dari limbah cair. Sehingga konsentrasi dari limbah cair akan tinggi pula. Titik terakhir merupakan titik pembanding dengan konsentrasi limbah cair dengan keadaan awalnya. 


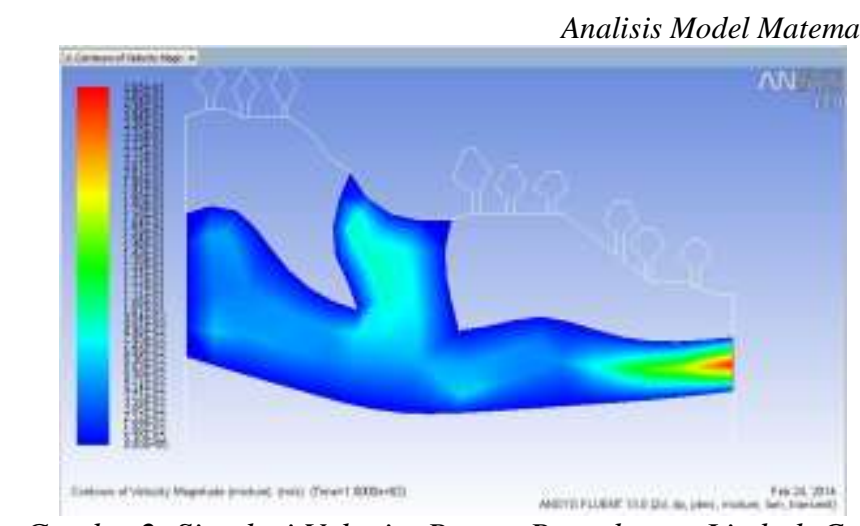

Gambar2. Simulasi Velocity Proses Penyebaran Limbah Cair

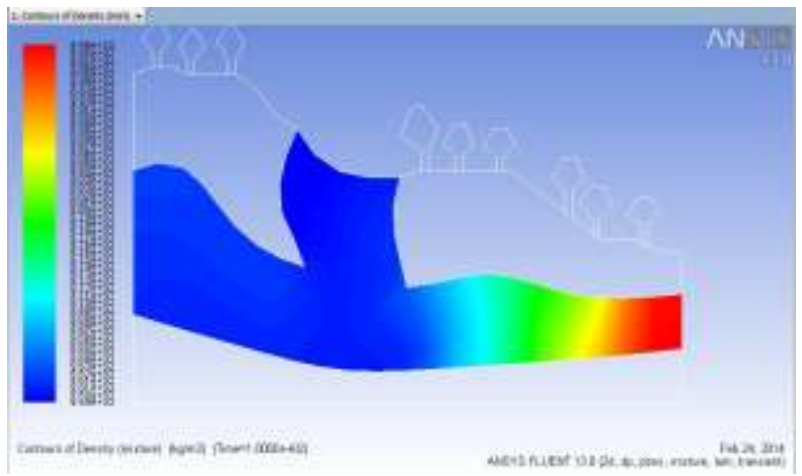

Gambar 3. Simulasi Kekentalan Proses Penyebaran Limbah Cair

Dari gambar simulasi (menggunakan Ansys FLUENT) kecepatan dari proses penyebaran limbah cair pada air tanah pada Gambar 2 dapat ditinjau bahwa konsentrasi limbah cair pada air tanah, semakin meresap kedalam tanah maka konsentrasi limbah semakin kecil, apabila limbah cair bertemu dengan air tanah maka limbah cair akan mengikuti aliran air tanah sehingga konsentrasi limbah cair pada air tanah akan menyebar pada daerah yang lebih rendah, dan mengumpul pada daerah terendah. Hal ini bisa dilihat dari gradasi warna biru menuju ke warna merah, dari keterangan dapat disimpulkan jika semakin merah warna dari simulasi maka akan semakin naik konsentrasinya. Penyebaran konsentrasi limbah cair pada Gambar 3 menunjukkan aliran berat jenis/kekentalan limbah cair tertinggi berada pada ujung outlet air tanah. Hal ini menunjukkan bahwa konsentrasi limbah cair akan berkumpul pada daerah yang lebih rendah atau daerah pantai. Jika hal ini terjadi secara terus menerus maka dapat membahayakan penduduk yang bertempat tinggal pada daerah tersebut 
7 | al-Khwarizmi, Volume III, Edisi 1, Maret 2015, Hal. 1 -8.

\section{Kesimpulan dan Saran}

Berdasarkan keterangan diatas dapat diambil kesimpulan bahwa:

1. Dalam proses penyebaran limbah cair pada air tanah, konsentrasi limbah cair akan terbawa air tanah menuju daerah yang lebih rendah atau pantai. Hal ini dapat dilihat pada gambar di FLUENT.

2. Kecepatannya akan turun pada panjang domain selanjutnya dan kemudian kembali naik. Hal ini dikarenakan terjadinya pencampuran 2 zat yaitu air tanah dan limbah cair, daerah yang memiliki kecepatan besar ada pada daerah yang berdampingan dengan inlet dari limbah cair. Sehingga konsentrasi dari limbah cair akan tinggi pula.

3. Persamaan penyebaran limbah cair pada air tanah adalah model yang efektif dalam menyelesaikan kasus penyebaran limbah cair pada air tanah karena persamaan ini eror relatifnya sebesar 0.000898124 atau sebesar $0.0898124 \%$.

Saran yang dapat diberikan setelah mengadakan penelitian ini adalah diharapkan bagi peneliti lain untuk meneliti dengan menggunkan metode yang lain seperti beda hingga, elemen hingga dan diselesaikan dengan software matematika yang lain semacam MAPLE, Matemateca dan lain-lain serta diteliti untuk pengaruh konsentrasi dan kedalaman air tanah tersebut. 
Analisis Model Matematika ...| 8

\section{DAFTAR PUSTAKA}

Arhani, M dan Desiani, A. 2004. Pemrograman Matlab. Yogyakarta: ANDI

Fatahillah, A. 2014, Analisis Numerik Profil Sedimentasi Pasir Pada Pertemuan Dua Sungai Berbantuan Software Fluent, Kadikma, Vol 5(3), Hal : 35-40

Tuakia, Firman. 2008. Dasar-dasar CFD Menggunakan FLUENT. Bandung: INFORMATIKA

Todd, D. K. and Mays, L. W. 2005. Groundwater Hydrology. Third edition. USA : John Wiley and Sons, Inc.

Wahid, F. 2003. Dasar-dasar Algoritma Pemrograman. Yogyakarta: ANDI 